\title{
On the water thermal response to the passage of cold fronts: initial results for Itumbiara reservoir (Brazil)
}

\author{
E. H. Alcântara ${ }^{1}$, M. P. Bonnet ${ }^{2}$, A. T. Assireu ${ }^{3}$, J. L. Stech ${ }^{1}$, \\ E. M. L. M. Novo ${ }^{1}$, and J. A. Lorenzzetti ${ }^{1}$ \\ ${ }^{1}$ National Institute for Space Research, Remote Sensing Division, São José dos Campos, SP, \\ Brazil \\ ${ }^{2}$ Université de Toulouse, UPS (OMP), IRD, LMTG, Toulouse, France \\ ${ }^{3}$ Federal University of Itajubá, Natural Resources Institute, Itajubá-MG, Brazil
}

Received: 10 November 2010 - Accepted: 26 November 2010 - Published: 7 December 2010 Correspondence to: E. H. Alcântara (enner@dsr.inpe.br)

Published by Copernicus Publications on behalf of the European Geosciences Union.

\section{Abstract}

The passage of meteorological systems such as cold fronts or convergence zones over reservoirs can cause significant modifications in several aquatic variables. Cold fronts coming from higher latitudes and reaching the Southeastern Brazilian territory modify 5 the mean wind field and have important impact over physical, chemical and biological processes that act in the hydroelectric reservoirs. The mean period of cold front passages along the Southeastern Brazilian coast is 6 days during the winter and between 11 and 14 days in the summer. Most of these fronts also affect the hinterland of São Paulo, Minas Gerais and Goiás states. The objective of this work is to ana-

10 lyze the influence of cold front passages in the thermal stratification and water quality of the Itumbiara hydroelectric reservoir which is located in Minas Gerais and Goiás. The characterization of cold front passages over the study area was done through the analysis of GOES satellite images. The analyzed data set includes time series of meteorological (wind direction and intensity, short-wave radiation, air temperature, relative 15 humidity, atmospheric pressure) and water temperature in four depths $(5,12,20$ and $40 \mathrm{~m}$ ). The data set was acquired in the interior of the reservoir by an autonomous anchored buoy system at a sampling rate of $1 \mathrm{~h}$. The stratification was assessed by non-dimensional parameter analysis. The lake number an indicator of the degree of stability and mixing in the reservoir was used in this analysis. We will show that during the cold front all atmospheric parameters respond and this response are transferred immediately to the water surface. The main effect is observed in the water column, when the heat loss in the surface allows the upwelling events caused by convective cooling due to the erosion of thermal stratification.

\section{Introduction}

25 Aquatic systems continually respond to atmospheric conditions (hydro-metrological processes) that span a broad space and time spectrum of scales. The primary modulation of the water temperature at a given location is given by the seasonal cycle 
of the incoming shortwave solar radiation. Superimposed on the seasonal cycle of temperature are shorter-term, irregular variations that occur in response to macro and meso-scale atmospheric disturbances such as cold fronts.

Cold fronts that affect the Brazilian territory normally form in the southern part of the

5 South American continent. Depending on their strength, some of these systems can progress northward to low latitudes, influencing great part of the country. The passage of fronts is normally associated to a drop of surface air temperature and pressure which are simultaneously accompanied by wind intensification. During the winter months cold fronts can reach the Southeast Brazilian coast each six days and during the summer

10 between eleven and fourteen days in average (Stech and Lorenzzetti, 1992). Most of these fronts reach the hinterlands of São Paulo, Minas Gerais and Goiás states.

Strong modification in physical, chemical and biological processes of hydroelectric reservoirs have been observed associated to the passage of frontal systems (Tundisi et al., 2004). The response of water bodies to meteorological conditions can be first re-

15 vealed by their vertical thermal structure (Ambrosetti and Barbanti, 2001). The precise knowledge of reservoir physical dynamics results of paramount relevance for hydrobiological and water quality studies as physical control of the biotic structure in reservoirs is even more important than in natural lakes (Uhlmann, 1998). Water temperature and heat dynamics have significant influence on the water quality and ecology of lakes and 20 reservoirs (Wetzel, 1983).

A few studies about the thermodynamics of water systems in Brazil were made such as Tundisi (1984), Henry and Barbosa (1989), Henry (1993). Tundisi et al. (2004) had explored the influence of cold fronts passage in the water quality in reservoirs and describes that most important finds of the cold front passage over a Brazilian hydroelectric reservoir is the release of iron and manganese due to the possibility to increase costs of the drink water treatment. However the authors don't shown and explain the impacts of the cold front passage in the heat exchange between water surface and the atmosphere and their implications to the thermal structure.

Based on this the objective of this paper is to show the influence of the passage of cold fronts in the thermal stratification cycle of a tropical hydroelectric reservoir in Brazil.

\section{Material and methods}

\section{$5 \quad 2.1$ Study area}

The Itumbiara hydroelectric reservoir $\left(18^{\circ} 25^{\prime} \mathrm{S}, 49^{\circ} 06^{\prime} \mathrm{W}\right)$ is located in a region stretched between Minas Gerais and Goiás States (Central Brazil) that was originally covered by tropical grassland savanna. The basin's geomorphology resulted in a lake with a dendritic pattern covering an area of approximately $814 \mathrm{~km}^{2}$ and a volume of 1017.03 billion $\mathrm{m}^{3}$.

The climate in the region is characterized by an average precipitation ranging from $2.0 \mathrm{~mm}$ in the dry season (May-September) to $315 \mathrm{~mm}$ in the rainy season (OctoberApril). In the rainy season the wind intensity ranges from 1.6 to $2.0 \mathrm{~m} \mathrm{~s}^{-1}$ and reaches up to $3.0 \mathrm{~m} \mathrm{~s}^{-1}$ in the dry season (Fig. 2a); the preferential wind direction is from south-

15 east to northwest. The air temperature in the rainy season ranges from 25 to $26.5^{\circ} \mathrm{C}$ and breaks down to $21^{\circ} \mathrm{C}$ in June as the dry season starts. The relative humidity has a pattern similar to that of the air temperature, but with a small shift in the minimum value towards September (47\%). Moreover, during the rainy season the humidity can reach $80 \%$ (see Fig. 2 b).

20 These hydro-meteorological patterns and the operational routine for energy generation drive the water level fluctuations in the reservoir (Fig. 3). The water level rising period starts in December and extends until May (with a mean period water change of $\frac{d C}{d t}=0.031 \mathrm{~m} \mathrm{day}^{-1}$ ); from May to June the water level is high (with a mean period water change of $0.006 \mathrm{~m} \mathrm{day}^{-1}$ ). Due to the use of water for power generation and evaporation rates, the water level recedes until November (with a mean period water change of $0.032 \mathrm{~m} \mathrm{day}^{-1}$ ). From November, the water reaches the low level condition until December (with a mean period water change of $0.023 \mathrm{~m} \mathrm{day}^{-1}$ ). 


\subsection{Satellite data}

The identification of the cold front passage over the Itumbiara reservoir was made using information of the Brazilian Centre for Weather Forecasting and Climate Studies - CPTEC/INPE, a specialized centre of climate analysis. The "CPTEC/INPE" provides

5 for South America the track of cold front passage and then published online (http: //climanalise.cptec.inpe.br/ rclimanl/boletim/). After the identification of the possibility of the front passage near or over the reservoir, the next step was to verify the extension of this cold front using satellite data.

The data of GOES-10 (Geostationary Operational Environmental Satellite) from 31 10 May to 6 June 2009 (from 151 to 157 in Julian day calendar) was used to capture the track of cold front pass over the Itumbiara reservoir. Using the satellite GOES data is possible to see the extension and the hour of the cold front passage over the reservoir. The Fig. 4 shows the evolution of the cold front passage over the reservoir and identifies the maximum activity of the front (Fig. 4b).

15 The identified period of cold front passage over the Itumbiara reservoir is positioned in the high water level regime, as shown in Fig. 3.

\subsection{Hydro-meteorological data}

The meteorological (air temperature, humidity, air pressure, intensity wind and shortwave radiation) and limnological (water temperature in 5, 12, 20 and $40 \mathrm{~m}$ depth) data 20 from 31 May to 6 June 2009 was collected by a moored buoy called SIMA (Integrated System for Environmental Monitoring, see Stech et al., 2006; Alcântara et al. 2010) in each $1 \mathrm{~h}$ (Fig. 5).

The characteristics of the sensors used to limnological and meteorological parameters are show in Table 1.

\subsection{Surface energy budget}

A study of the energy exchange between the lake and atmosphere is essential for understanding the aquatic system behavior and its reaction to possible changes of environmental and climatic conditions (Bonnet et al., 2000). The exchange of heat across 5 the water surface was computed using the methodology described by HendersonSellers (1986) as:

$\phi_{N}=\phi_{\mathrm{s}}(1-A)-\left(\phi_{\mathrm{ri}}+\phi_{\mathrm{sf}}+\phi_{\mathrm{If}}\right)$,

where $\phi_{N}$ is the surface heat flux balance, $\phi_{\mathrm{s}}$ is the incident short-wave radiation (measured direct by SIMA buoy), $A$ is the albedo of water $(=0.07), \phi_{\mathrm{ri}}$ is the Longwave 10 flux, $\phi_{\text {sf }}$ is the sensible heat flux and $\phi_{\text {If }}$ is the latent heat flux. The units used for the terms in Eq. (1) are $\mathrm{Wm}^{-2}$. These terms are defined as positive when directed into the water.

The net longwave radiation corresponding to the outgoing flux minus the incoming flux (LW $\uparrow \downarrow=L W \uparrow-L W \downarrow), \phi_{\text {ri }}$ is computed as given by Fung et al. (1984):

${ }_{15} \phi_{\mathrm{ri}}=\varepsilon \sigma T_{\mathrm{s}}^{4}\left(0.39-0.05 e_{\mathrm{a}}^{\frac{1}{2}}\right)(1-\lambda C)+4 \varepsilon \sigma T_{\mathrm{s}}^{3}\left(T_{\mathrm{s}}-T_{\mathrm{a}}\right)$,

where $\varepsilon=0.97$ is the thermal infrared emissivity of the water, $\sigma$ is the Stefan-Boltzmann constant, $T_{\mathrm{s}}=$ water surface temperature $(\mathrm{K}), T_{\mathrm{a}}=$ surface air temperature $(\mathrm{K}), \lambda=0.8$ is the Reed (1977) correction factor, and $e_{\mathrm{a}}=$ partial pressure of vapor $(\mathrm{mb})$, which was calculated as:

$20 e_{\mathrm{a}}=r e_{\text {sat }}\left(T_{\mathrm{a}}\right)$,

where $r$ is the relative humidity and $e_{\text {sat }}$ is the saturation vapor pressure. This was calculated using the polynomial approximation of Lowe (1977).

The non-radiative energy term $\phi_{\text {rad }}$ accounts for the sensible heat flux and latent heat flux. The sensible heat flux was calculated as (Large et al., 1997):

${ }_{25} \phi_{\mathrm{sf}}=\rho_{\mathrm{a}} c_{p} c_{H}|\vec{V}|\left(T_{\mathrm{s}}-T_{\mathrm{a}}\right)$, 
where $\phi_{\mathrm{sf}}$ is the sensible heat flux $\left(\mathrm{Wm}^{-2}\right), \rho_{\mathrm{a}}=1.2 \mathrm{~kg} \mathrm{~m}^{-3}$ is the air density, $c_{p}=1.005 \times 10^{3} \mathrm{~J} \mathrm{~kg}^{-1} \mathrm{~K}^{-1}$ is the specific heat capacity of air, $c_{H}=1.1 \times 10^{-3}$ is the coefficient of turbulent exchange and $|\vec{V}|=$ surface wind speed $\left(\mathrm{m} \mathrm{s}^{-1}\right)$.

The latent heat flux was computed as follows (Large et al., 1997):

$5 \quad \phi_{\text {If }}=\rho_{\mathrm{a}} c_{\mathrm{E}} L|\vec{V}|\left[e_{\mathrm{sat}}\left(T_{\mathrm{s}}\right)-r e_{\text {sat }}\left(T_{\mathrm{a}}\right)\right] \frac{0.622}{p_{\mathrm{a}}}$.

where $\phi_{\text {If }}$ is the latent heat flux $\left(\mathrm{W} \mathrm{m}^{-2}\right), c_{\mathrm{E}}=1.1 \times 10^{-3}$ is a coefficient of turbulent exchange, $L=2.501 \times 10^{6} \mathrm{~J} \mathrm{~kg}^{-1}$ is the vaporization of latent heat and $p_{\mathrm{a}}$ is the atmospheric surface pressure $(\mathrm{mb})$.

The energy exchange also occurs through precipitation, withdrawal of evaporated 10 water, chemical and biological reactions in the water body, and conversion of kinetic to thermal energy. These energy terms are small enough to be omitted. Many researchers agree that omitting energy budget components with small values does not significantly affect the results (Bolsenga, 1975; Sturrock et al., 1992; Winter et al., 2003).

\subsection{Lake number $-L_{N}$}

To indicate the degree of stability and mixing in the reservoir, due to the passage of cold front, the $L_{N}$ was used (Imberger and Patterson, 1990).

$\mathrm{L}_{N}=\frac{g S_{t}\left(1-\frac{z_{T}}{H}\right)}{\rho u_{*} A^{1.5}\left(1-\frac{z_{g}}{H}\right)}$,

where $g$ is gravity, $\rho$ is the density of water, $z_{T}$ is the height to the center of the metalimnion, $z_{g}$ is the height to the center of volume of the lake, $A$ is lake area, $H$ is the

depth of the lake, $u_{*}$ is the friction velocity in water and $S_{t}\left(\mathrm{~g} \mathrm{~cm}^{-1} \mathrm{~cm}^{-2}\right)$ is an estimate of the stability of the reservoir calculated as (Hutchinson, 1957):

$S_{t}=\int_{0}^{z m}\left(z-z_{g}\right) A(z) \rho(z) d z$,

where $z_{g}$ can be obtained as:

$5 z_{g}=\frac{\int_{0}^{z m} z A(z) d z}{\int_{0}^{z m} A(z) d z}$,

The $L_{N}$ characterizes the dynamic stability of a lake (Imberger and Patterson, 1990) and is a ration of moments about the center of lake volume of the wind force at the surface of the lake and the gravity restoring force to the stratification. To calculate the $L_{N}$ the reservoir bathymetry are needed.

\subsubsection{Bathymetric data}

The bathymetry of the Itumbiara reservoir was made in two campaigns, the first from 11-15 May 2009 and second from 11-16 August 2009. The depth data was collected using an echo-sound LMS-525 from Lowrance, with a GPS (Global Positioning System) coupled. The depth data was treated in accordance to Merwade (2009).

\section{2.5.2 Area and volume of the reservoir}

To compute the area and volume of the reservoir the depths was separated into ten intervals depths (from 0 to $78.5 \mathrm{~m}$ ); this was done to simplify the computation. The change in area and volume will evaluate using the derivative analysis applied in the water level table to accesses the rate of change (see Fig. 3) from 31 May to 6 June 
2009. The area was calculated using the GIS-based approach (ESRI, 2004) and the volume by (Chapra, 1997):

$V=\int_{0}^{z} A(z) d z$

where $A$ is the area $\left(\mathrm{m}^{2}\right)$ in a depth $z(\mathrm{~m})$.

\subsection{Brunt-Väisälä frequency $\left(N^{2}\right)$}

Vertical water column is locally stable if a fluid parcel that is displaced isentropically from its initial position by an infinitesimal vertical distance $(d z)$ always experiences a restoring force. This localized displacement will be measured using the Brunt-Väisälä or buoyancy frequency, as (Pond and Pickard, 1983):

${ }_{10} N^{2}=-\left(\frac{g}{\rho}\right) \frac{\partial \rho}{\partial z}$,

where $g$ is gravity, $\rho$ is the water density and $z$ is depth. The water column is locally stable if $N^{2}>0$, unstable if $N^{2}<0$, and neutrally stable if $N^{2}=0$ (Peeters et al., 1996).

The water density $\left(\rho, \mathrm{kg} \mathrm{m}^{-3}\right)$ was estimated as a function of water temperature $\left(T_{\mathrm{s}}\right)$ using the following equation (Ford, 1990):

${ }_{15} \rho=999.8452594+6.793952 \times 10^{-2} T_{\mathrm{s}}-9.095290 \times 10^{-3} T_{\mathrm{s}}^{2}+1.001685 \times 10^{-4} T_{\mathrm{s}}^{3}$

$-1.120083 \times 10^{-6} T_{s}^{4}+6.536332 \times 10^{-9} T_{s}^{5}$.

\section{Results and discussion}

\subsection{Bathymetric map}

The result of the depth surveys shows that the reservoir presents the highest depths in

the line of flooded river with depths higher than $78 \mathrm{~m}$ during the high water level; with 9445

a littoral zone with depth less than $2 \mathrm{~m}$. Other deeper region is near the Dam where the depth reaches $70 \mathrm{~m}$ (Fig. 6).

\subsection{Meteorological and limnological data}

The Fig. 7 shows the meteorological and limnological parameters used in this study.

5 It is clear that during the passage of cold front the atmospheric pressure and the air temperature decrease; in the other hand the wind shows a little increase and also the relative humidity. The water surface temperature decreases after the passage of the cold front.

\subsection{Heat flux budget}

10 This pattern observed before, during and after the passage of cold front is reflected in each component of the heat flux balance (Fig. 8). During the passage of the cold front the intensity of the shortwave radiation decreases. The shortwave radiation presented a variable peaks in this day, represented by the perturbation in the atmospheric boundary-layer; than during 1 June 2009 the shortwave radiation was reduced from $15680 \mathrm{~W} \mathrm{~m}^{-2}$ to $280 \mathrm{~W} \mathrm{~m}^{-2}$.

The sensible flux tends to be higher during and after the cold front passage if compared the period before the passage. The latent flux during the passage of the cold front tends to decrease, but after the passage the latent flux tents to increase again. The heat balance before the passage of cold front is positive when shortwave act in the

20 systems; however during the passage the balance is negative and tends to normalize with the dissipation of the front.

This was reflected in the air temperature decrease and the increase of humidity in the reservoir (Fig. 7). The enhancement of the sensible heat flux is due to the convection caused by decrease in the atmospheric stability. The sensible flux is proportional to the temperature difference between the water surface and the overlying atmosphere and also dependent on intensity of turbulent mixing. 
In the other hand the latent flux tends to be smaller before the cold passage and higher after the passage. The turbulent exchanges of heat and water vapor over an open water surface are affected by many environmental factors. It is well known that evaporation rates over a water surface depend largely on vapor pressure deficits be-

5 tween water surfaces and the overlying atmosphere as well as on intensity of turbulent mixing (Henderson-Sellers, 1986). The air is always at its saturation at the interface between the water and the overlying air, and the saturation pressure in this interface is a function of water surface temperature (Hostetler and Bartlein, 1990).

The increasing in the longwave radiation after the passage of the cold front is due 10 to the cloud cover formation. During cloud days the atmospheric longwave radiation is often the greatest source of heat at the water surface (Henderson-Sellers, 1986). Probably the observed increase in the latent heat flux could be linked with the back heat into the water by the longwave radiation.

The alterations in meteorological and heat flux data will be reflected in the heat

15 content stored in the reservoir. The heat content $(\zeta, \mathrm{cal})$ for given water volume stored in the reservoir can be calculated using the formulation given by Chapra and Reckhow (1983):

$$
\varsigma=t \rho C V
$$

where $t$ is the water temperature $\left({ }^{\circ} \mathrm{C}\right), \rho$ is the water density $\left(\mathrm{g} \mathrm{cm}^{-3}\right), C$ is the specific 20 heat of water $\left(\mathrm{cal} \mathrm{g}^{-1}{ }^{\circ} \mathrm{C}^{-1}\right)$, and $V$ the water volume $\left(\mathrm{cm}^{3}\right)$.

To transform the water temperature into heat $\left(\varsigma_{\mathrm{H}}, \mathrm{cal}\right)$ it has been assumed that the volume of a gram of water is $1 \mathrm{ml}$, and that the specific heat of the water is $1 \mathrm{cal} \mathrm{g}^{-1}{ }^{\circ} \mathrm{C}^{-1}$ (Wetzel and Likens, 2000):

$\varsigma_{\mathrm{H}}=\sum_{Z_{0}}^{Z_{\max }} t_{Z} A_{Z} h_{Z}$

where $t_{z}$ the average temperature of the water of a unity in layer $h_{z}(\mathrm{~cm})$, and $A_{z}$ is the average surface of the layer $z\left(\mathrm{~cm}^{2}\right)$. Heat content results were linearly interpolated to daily values.

The Fig. 9 shows the heat content evolution. In the first day before the passage the 5 reservoir losses $81.57 \mathrm{cal} \mathrm{cm}^{-2}$ of the heat content; at the end of six days before the front passage the reservoir losses $569 \mathrm{cal} \mathrm{cm}^{-2}$.

Note that the progressively loss of energy from water to the atmosphere is associated in the first instance to the cold front passage; but when the cold front dissipate the shortwave radiation reach again their pattern value $\sim 700 \mathrm{~W} \mathrm{~m}^{-2}$. In this case the sink-

10 ing of heat is the upwelling caused by convective cooling due to the erosion of thermal stratification.

The other parameter that could be taken in consideration is the persistence of the wind action on the water surface. The autocorrelation analysis is a way of measuring linear dependence between observations of a time series (Box et al., 1994), and is 15 suitable to measure the persistence of wind (Koçak, 2008).

The autocorrelation function applied to the wind data shows that the persistence is less than four hours (Fig. 10). This result reveals that during the passage of the cold front over the Itumbiara reservoir, the wind blows over the surface area almost for $4 \mathrm{~h}$ and then the wind become intermittent.

20 The combined effect of wind persistence, decrease of the air temperature and shortwave radiation, causes an increase of latent flux (due to the difference between the air and water temperature) and sensible (due to the atmospheric instability) was the primary physical disturbance capable to decrease the upper most layer of the water column and then by convection transfer the cooling water for the subsequent layers.

\section{$25 \quad 3.4 \quad$ Lake number analysis}

This heat content modification due to the cold front will reflect in the water column temperature and stability (Fig. 11a). Before the passage of the front the water column presented a little temperature difference between the epilimnion and metalimnion; with 
the passage of the cold front the water temperature of the top-most layer decrease and the difference of temperature in the water column decreases also.

The analysis of lake number $\left(L_{N}\right)$ are show in Fig. 11b. When $L_{N}>1$ there is no deep upwelling and when $L_{N}<1$ the cold deep, often nutrient rich, water from the hypolimnion

5 will reach the surface layer during the wind episode (Antenucci and Imberger, 2003). For $L_{N}$ as high as 60 , little turbulent mixing is expected in the hypolimnion (Hondzo and Stefan, 1996). In this case all $L_{N}>1$ occurred during the daytime when the incident shortwave radiation is present, but after the passage of the cold front the values of $L_{N}$ increase during the heating phase. Often $L_{N}<1$ occurred during the nighttimes, the unique exception is the day during the cold passage with $L_{N}$ less than 1 .

After the passage of the front the water from hypoliminion progressively cooler and the mixed layer goes up to the top layer. The fact of the $L_{N}$ increases after the front passage during the daytime could be explained by the fact that during the cold front passage the water losses energy to the atmosphere and when the cold front dissipate

15 the incident shortwave radiation heats the surface creating the condition enhancing the stability of the water column. The local stability of the water column was estimated using the Brunt-Väisälä frequency, as follows.

\subsection{Brunt-Väisälä frequency}

The Brunt-Väisälä shows (Fig. 12) that before the cold front passage the stratification 20 was stable $\left(N^{2}>0\right)$ during the daytime and less stable during night. During the cold front passage the stability of the stratification was destroyed and the system mixing $\left(N^{2}=0\right)$. After the cold passage the system back to stable stratification during day and vertical mixing during night.

The Brunt-Väisälä shows that the turbulent layer is about $20 \mathrm{~m}\left(N^{2}=0\right)$. In very few 25 cases the turbulent depths reaches $40 \mathrm{~m}$; when this occur the water column overturn. This complete vertical mixing at the metalimnion level erodes the imposed barrier imposed by the stratification (more commonly during daytime before the cold front) and facilitates the availability of nutrient-rich hypolimnetic waters increasing the primary production (Ostrovsky et al., 1996).

\section{Conclusions}

This works shows the influence of cold front passage over a tropical hydroelectric reservoir in the meteorological, near-surface heat flux and consequently in the thermal structure of the water column.

5 The time series of meteorological and limnological variables provided a good view of the importance of meteorological systems to the stratification/mixing process in tropical reservoirs such as those studied. The passage of cold front over a region decreases the atmospheric pressure and air temperature, enhancing the relative humidity. With the formation of cloud cover the longwave radiation increase and transfer heat by tur-

10 bulent convection to the water surface. The sensible flux presents a small variability but an increase occurs due to a convective turbulence caused by front passage; in other hand the latent flux decrease but insufficiently to cause a condensation, just the evaporation decreases. The upwelling events are the responsible to maintain the loss of heat after the cold front passage.

15 Acknowledgements. The authors would like to thank the FAPESP Project 2007/08103-2, INCT for Climate Change project (grant 573797/2008-0 CNPq) and FURNAS Centrais Elétricas. Enner Alcântara thanks CAPES and CNPq under grants 0258059 and 140316/2010-8, respectively.

\section{References}

20 Alcântara, E., Novo, E., Stech, J., Lorenzzetti, J., Barbosa, C., Assireu, A., and Souza, A.: A contribution to understanding the turbidity behaviour in an Amazon floodplain, Hydrol. Earth Syst. Sci., 14, 351-364, doi:10.5194/hess-14-351-2010, 2010.

Alcântara, E., Stech, J., Lorenzzetti, J., Bonnet, M., Casamitjana, X., Assireu, A., and Novo, E.: Remote sensing of water surface temperature and heat flux over a tropical hydroelectric reservoir, Remote Sens. Environ., 114, 2651-2665, 2010.

Ambrosetti, W. and Barbanti, L.: Temperature, heat content, mixing and stability in Lake Orta: a pluriannual investigation, J. Limnol., 60, 60-68, 2001.

Antenucci, J. and Imberger, J.: The seasonal evolution of wind/internal wave resonance in Lake Kinneret, Limnol. Oceanogr., 48, 2055-2061, 2003. 
Bolsenga, S.: Estimating energy budget components to determine Lake Huron evaporation, Water Resour. Res., 11, 661-666, 1975.

Bonnet, M. P., Poulin, M., and Devaux, J.: Numerical modeling of thermal stratification in a lake reservoir: methodology and case study, Aquat. Sci., 62, 105-124, 2000.

5 Box, G. E. P., Jenkins, G. M., and Reinsel, G. C.; Time Series Analysis: Forecasting and Control, 3rd edn., Prentice Hall, Englewood Cliffs, NJ, USA, 1994.

Chapra, S. C.: Surface Water-Quality Modeling, McGraw-Hill, New York, 1997.

Chapra, S. C. and Reckhow, K. H.: Engineering approaches for lake management, in: Mechanistic Modeling, Vol. 2, Butterworth Publishers, Boston, p. 492, 1983.

10 ESRI: ArcGIS 9: Using ArcGIS 3-D analyst, ESRI Press, New York, USA, 390 pp., 2004.

Ford, D. E.: Reservoir transport processes, in: Reservoir Limnology: Ecological Perspectives, edited by: Thornton, K. W., Kimmel, B. L., and Payne, F. E., Wiley-Interscience, New York, 15-41, 1990.

Fung, I. Y., Harrison, D. E., and Lacis, A. A. On the variability of the net longwave radiation at the ocean surface, Rev. Geophys., 22, 177-193, 1984.

Henderson-Sellers, B.: Calculating the surface energy balance for lake and reservoir modeling: a review, Rev. Geophys., 24, 625-649, 1986.

Henry, R.: Thermal regime and stability of Jurumirim reservoir (Paranapanema River, Sao Paulo, Brazil), Int. Revue Ges. Hydrobiol., 78, 501-511, 1993.

20 Henry, R. and Barbosa, F. A.: Thermal structure, heat content and stability of two lakes in the National Park of rio Doce Valley (Minas Gerais, Brazil), Hydrobiologia, 171, 189-199, 1989.

Hondzo, M. and Stefan, H. G.: Long-term lake water quality predictors, Water Res., 30, 28352852, 1996.

Hostetler, S. W. and Bartlein, P. J.: Simulation of lake evaporation with application to modeling

25 lake level variations of Harney-Malheur Lake, Oregon, Water Resour. Res., 26, 2603-2612, 1990.

Hutchinson, G. E.: A Treatise on Limnology, Geography, Physics and Chemistry, John Wiley, John Wiley, New York, 1015 pp., 1957.

Imberger, J. and Patterson, J. C.: Physical limnology, Adv. Appl. Mech., 27, 303-475, 1990.

30 Kocak, K.: Practical ways of evaluating wind speed persistence, Energy, 33, 65-70, 2008.

Large, W. G., Danabasoglu, G., and Doney, S. C.: Sensitivity to surface forcing and boundary layer mixing in a global ocean model: annual-mean climatology, J. Phys. Oceanogr., 27, 2418-2447, 1997.

9451

Lowe, P. R.: An approximating polynomial for the computation of saturation vapor pressure, J. Appl. Met., 16, 100-103, 1977.

Merwade, V.: Effect of spatial trends on interpolation of river bathymetry, J. Hydrol., 371, 169181,2009

5 Ostrovsky, I., Yacobi, Y. Z., Walline, P., and Kalikhaman, I.: Seiche-induced mixing: its impact on lake productivity, Limnol. Oceanogr., 41, 323-332, 1996.

Peeters, F., Piepke, G., Kipfer, R., Hohmann, R., and Imboden, D. M.: Description of stability and neutrally buoyant transport in freshwater lakes, Limnol. Oceanogr., 41, 1711-1724, 1996.

10 Pond, S. and Pickard, G. L.: Introductory Dynamical Oceanography, Pergamon Press, Oxford, 1983.

Reed, R.: On estimating insolation over the ocean, J. Phys. Oceanogr., 7, 482-485, 1977.

Stech, J. L. and Lorenzzetti, J. A.: The response of the South Brazil Bight to the passage of wintertime cold fronts, J. Geophys. Res., 97, 9507-9520, 1992.

15 Stech, J. L., Lima, I. B. T., Novo, E. M. L. M., Silva, C. M., Assireu, A. T., Lorenzzetti, J. A., Carvalho, J. C., Barbosa, C. C. F., and Rosa, R. R.: Telemetric monitoring system for meteorological and limnological data acquisition, Verh. Internat. Verein. Limnol., 29, 1747-1750, 2006.

Sturrock, A., Winter, T., and Rosenberry, D.: Energy budget evaporation from Williams Lake: a closed lake in North Central Minnesota, Water Resour. Res., 28, 1605-1617, 1992.

Tundisi, J. G.: Estratificação hidráulica em reservatórios e suas conseqüências ecológicas, Cienc. Cult., 36, 1489-1496, 1984.

Tundisi, J. G., Matsumura-Tundisi, T., Arantes Junior, J. D., Tundisi, J. E. M., Manzini, N. F., and Ducrot, R.: The response of Carlos Botelho (Lobo, Broa) Reservoir to the passage of cold

25 fronts as reflected by physical, chemical and biological variables, Braz. J. Biol., 64, 177-186, 2004.

Uhlmann, D.: Reservoirs as ecosystems, Internat. Rev. Hydrobiol., 83, 13-20, 1998.

Wetzel, R. G.: Limnology, Saunders Coll, Philadelphia, 1983.

Wetzel, R. G. and Likens, G. E.: Limnological Analysis. 3rd edn., Springer, New York, 2000.

30 Winter, T., Buso, D., Rosenberry, D., Likens, G., Sturrock, J. R. A., and Mau, D.: Evaporation determined by the energy-budget method for Mirror Lake, New Hampshire, Limnol. Oceanogr., 48, 995-1009, 2003. 
Table 1. Characteristics of the limnological and meteorological sensors installed at SIMA.

\begin{tabular}{lcccc}
\hline Sensor & Manufacture & Range & Accuracy & Depth/height \\
\hline \multicolumn{5}{c}{ Limnological } \\
\hline Water temperature & Yellow Spring & $-5-60^{\circ} \mathrm{C}$ & $\pm 0.15^{\circ} \mathrm{C}$ & $-1.5 \mathrm{~m}$ \\
\hline Mir temperature & Rotronic & $-50-100{ }^{\circ} \mathrm{C}$ & $\pm 0 .{ }^{\circ} \mathrm{C}$ & $3 \mathrm{~m}$ \\
Air pressure & Vaisala & $800-1060 \mathrm{mb}^{-}$ & $\pm 0.3 \mathrm{mb}$ & $3 \mathrm{~m}$ \\
Wind & R. M. Young & $0-100 \mathrm{~m} \mathrm{~s}^{-1}$ & $\pm 0.3 \mathrm{~m} \mathrm{~s}^{-1}$ & $3 \mathrm{~m}$ \\
Humidity & Rotronic & $0-100 \%$ & $\pm 1.5 \%$ & $3 \mathrm{~m}$ \\
Shortwave & Novalynx & $0-1500 \mathrm{~W} \mathrm{~m}^{-2}$ & $\pm 5 \%$ & $3 \mathrm{~m}$ \\
\hline
\end{tabular}
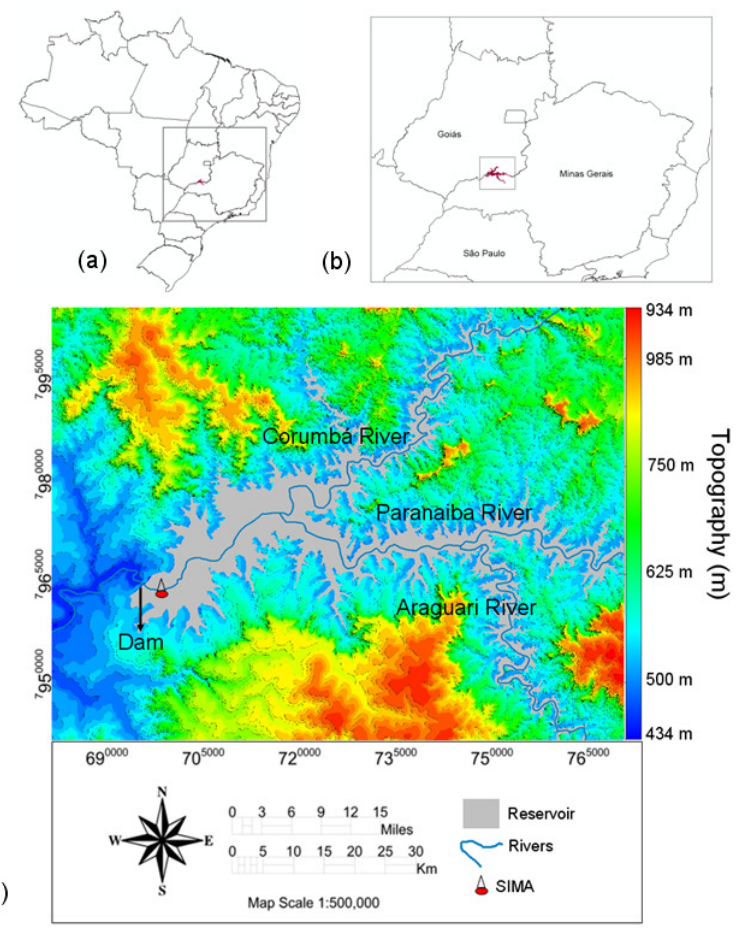

Fig. 1. Itumbiara reservoir location in Brazil (a), between Minas Gerais and Goias States (b) and the topography $(\mathrm{m})$ near the reservoir and the location of the moored buoy (c). 

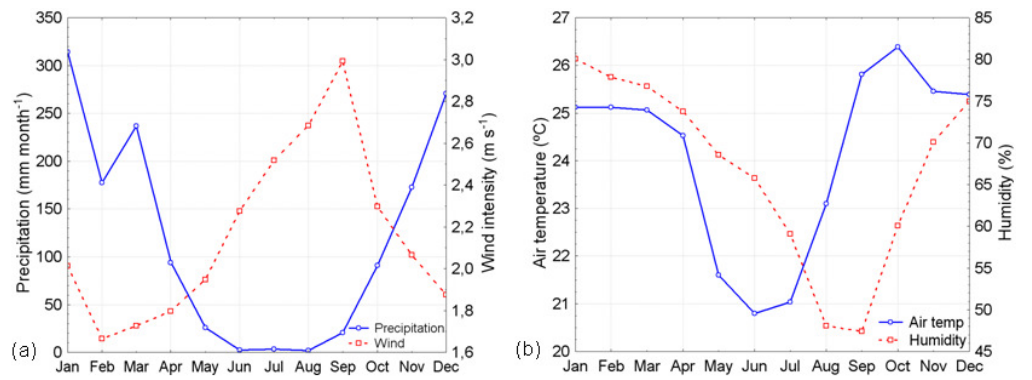

Fig. 2. Climate patterns of Itumbiara reservoir: average (2003-2008) monthly mean of (a) precipitation $\left(\mathrm{mm} \mathrm{month}^{-1}\right)$ and wind intensity $\left(\mathrm{m} \mathrm{s}^{-1}\right)$, (b) air temperature $\left({ }^{\circ} \mathrm{C}\right)$ and humidity (\%).

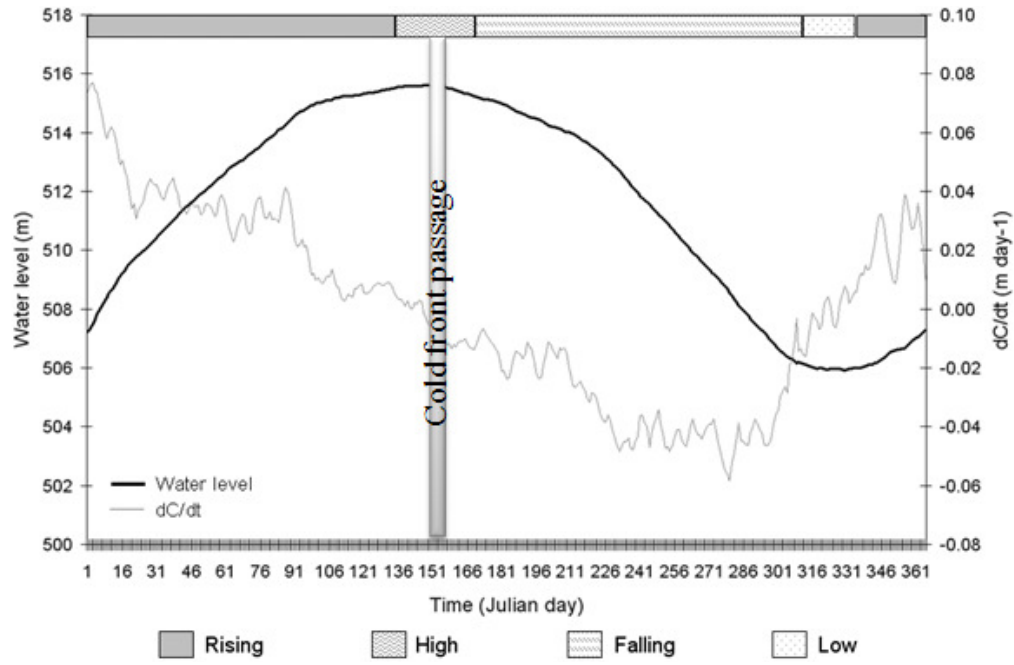

Fig. 3. Daily averages (from 2003 to 2008) of water level fluctuation at Itumbiara reservoir $(C)$ their changer over time, $t$, and the passage of cold front (Alcântara et al., 2010). 


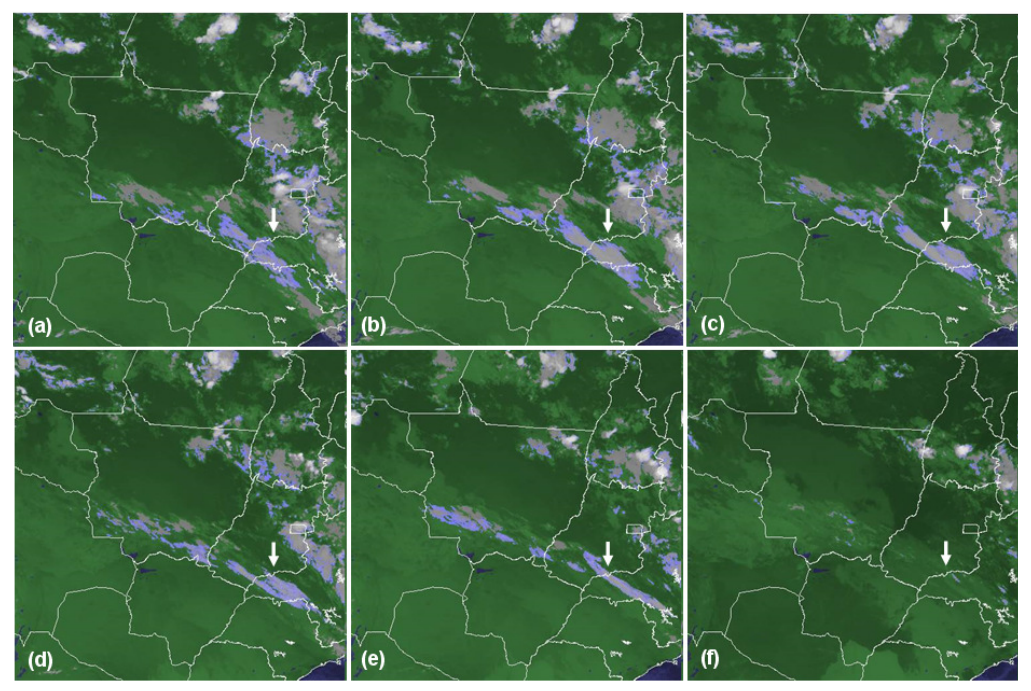

Fig. 4. GOES-10 satellite image (visible: $0.52-0.72 \mu \mathrm{m}$ ) showed the evolution of the cold front passage over the reservoir: (a) 1 June 2009 at 05:15 h, (b) 1 June 2009 at 06:15 h, (c) 1 June 2009 at 07:00 h, (d) 1 June 2009 at 08:00 h, (e) 1 June 2009 at 09:45 h (f) 1 June 2009 at 13:00 $\mathrm{h}$. The arrows indicate the location of the reservoir.

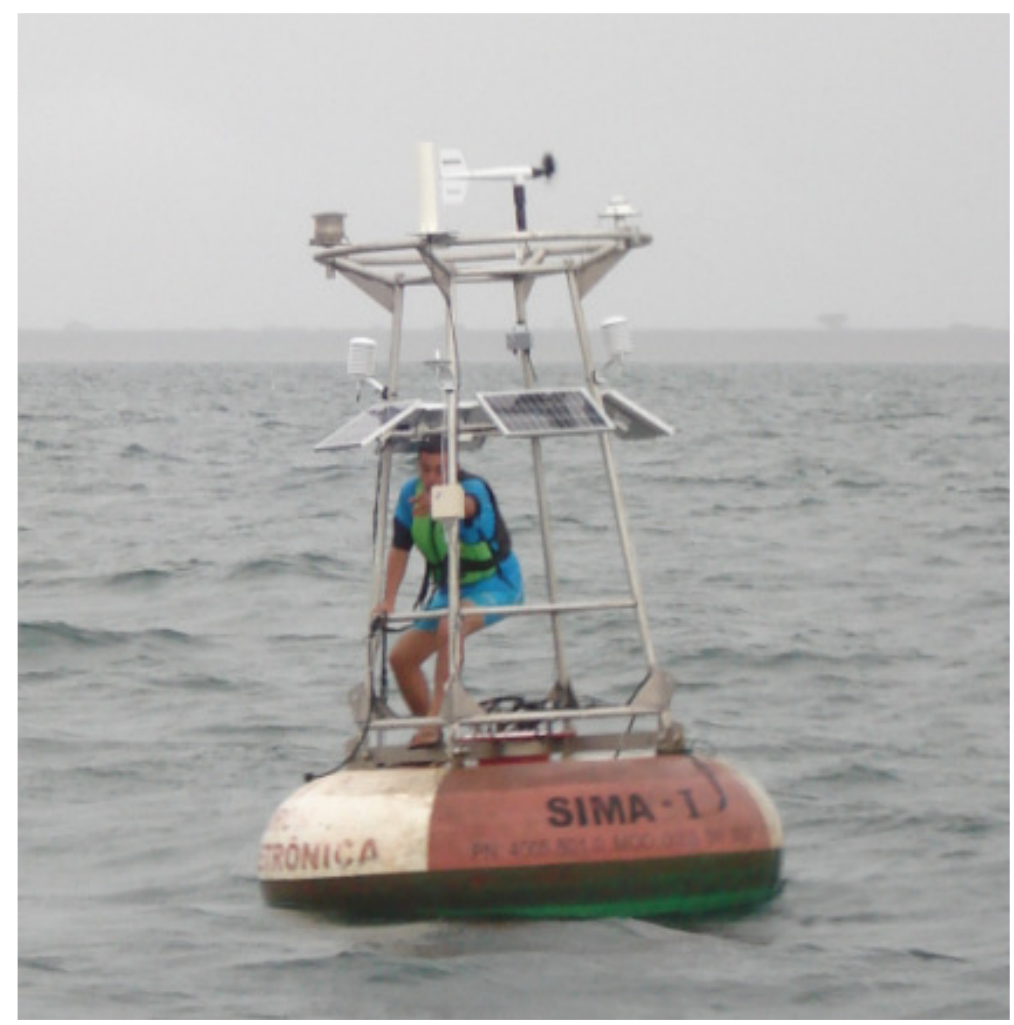

Fig. 5. Photo of SIMA installed at Itumbiara reservoir (see Fig. 1 for location). 

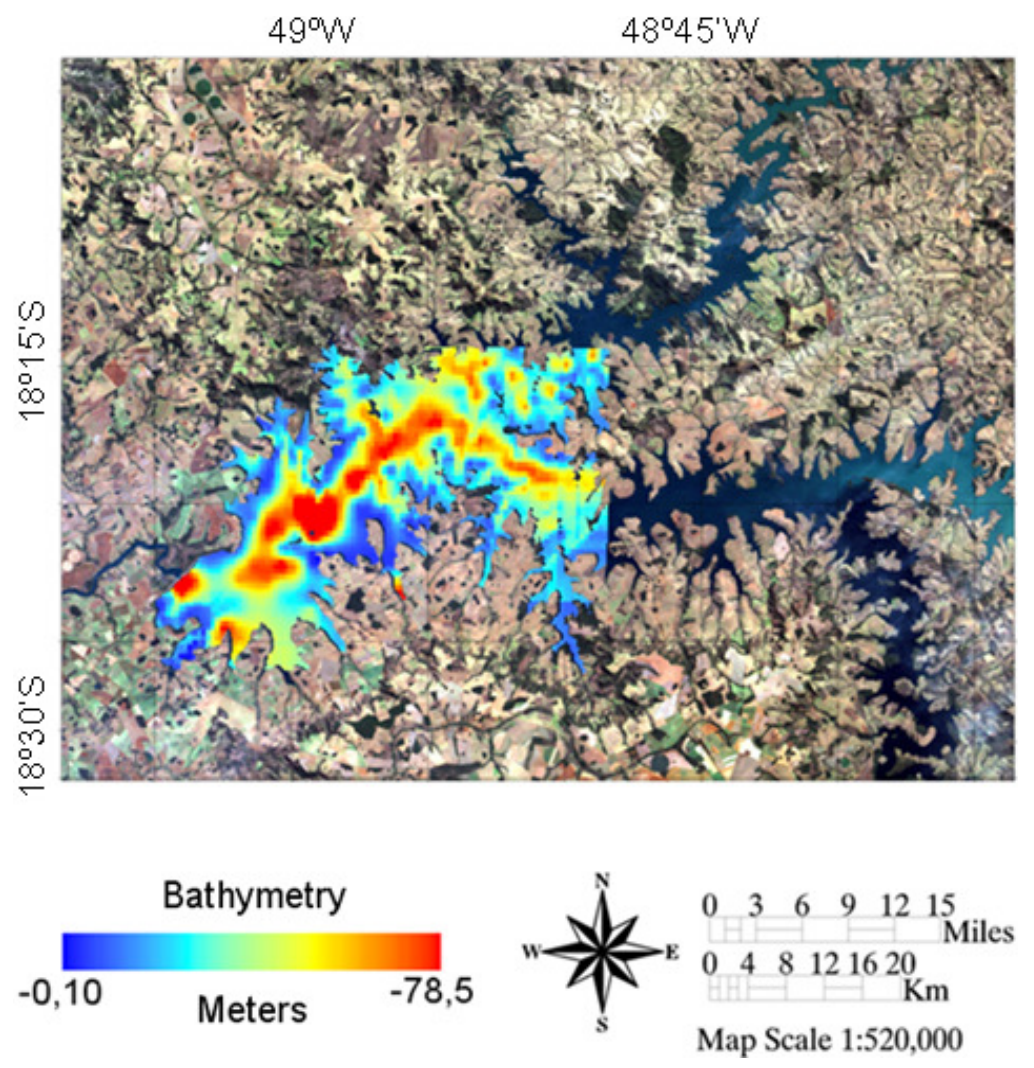

Fig. 6. Bathymetric map of the Itumbiara reservoir.

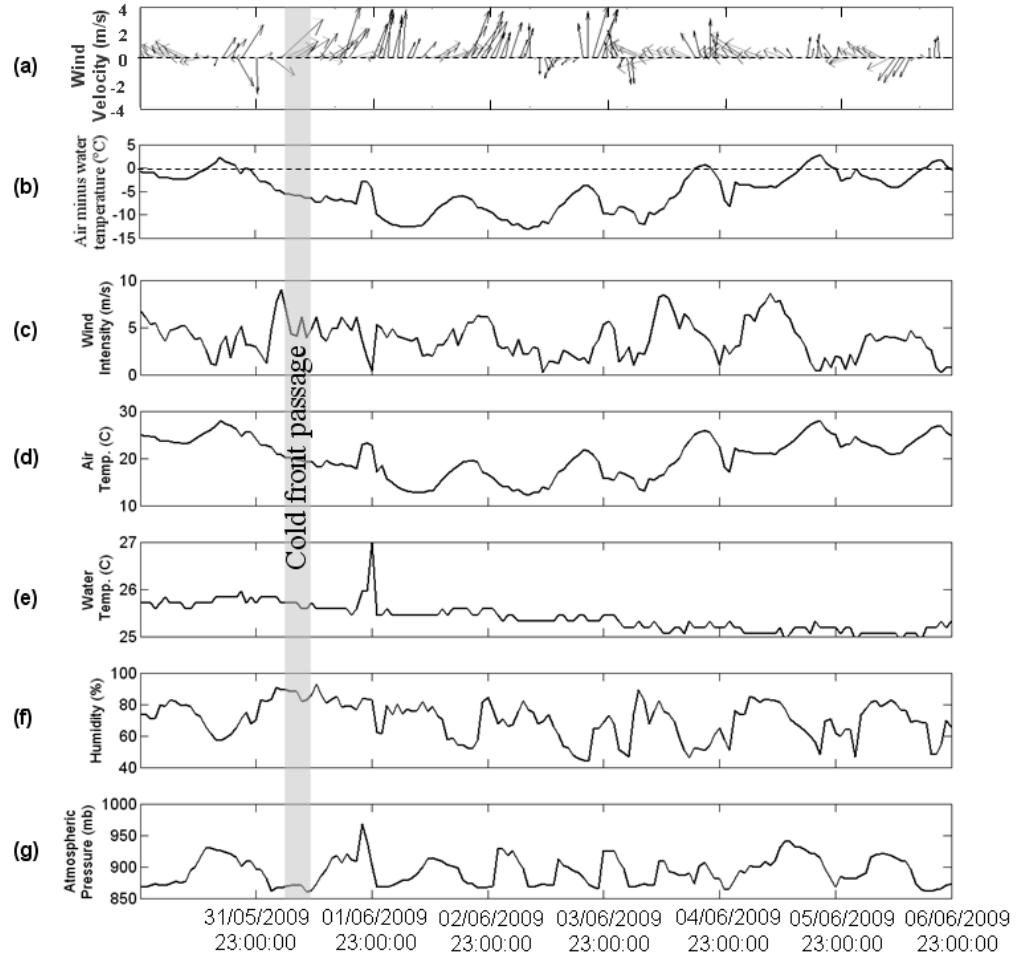

Fig. 7. Meteorological and limnological time series data: (a) stick plot of wind velocity $\left(\mathrm{m} \mathrm{s}^{-1}\right)$, (b) air minus water temperature $\left({ }^{\circ} \mathrm{C}\right)$; (c) wind intensity $\left(\mathrm{m} \mathrm{s}^{-1}\right)$, (d) air temperature $\left({ }^{\circ} \mathrm{C}\right)$, (e) water temperature; (f) relative humidity $(\%),(\mathbf{g})$ atmospheric pressure $(\mathrm{mb})$ collected by the SIMA buoy from 31 May to June 62009. 

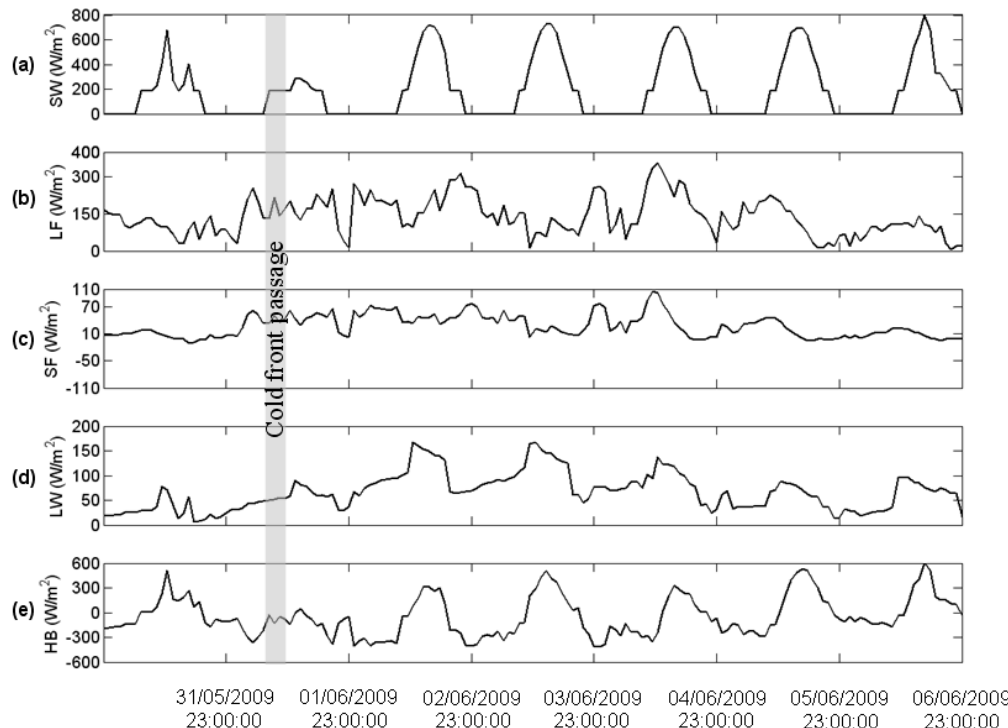

Fig. 8. Heat flux components: (a) $\mathrm{SW}$ - shortwave radiation $\left(\mathrm{W} \mathrm{m}^{-2}\right)$, (b) $\mathrm{LF}$ - latent flux $\left(\mathrm{Wm}^{-2}\right)$, (c) SF - sensible flux $\left(\mathrm{W} \mathrm{m}^{-2}\right)$, (d) $\mathrm{LW}-$ longwave radiation $\left(\mathrm{Wm}^{-2}\right)$ and (e) $\mathrm{HB}-$ heat balance $\left(\mathrm{Wm}^{-2}\right)$.

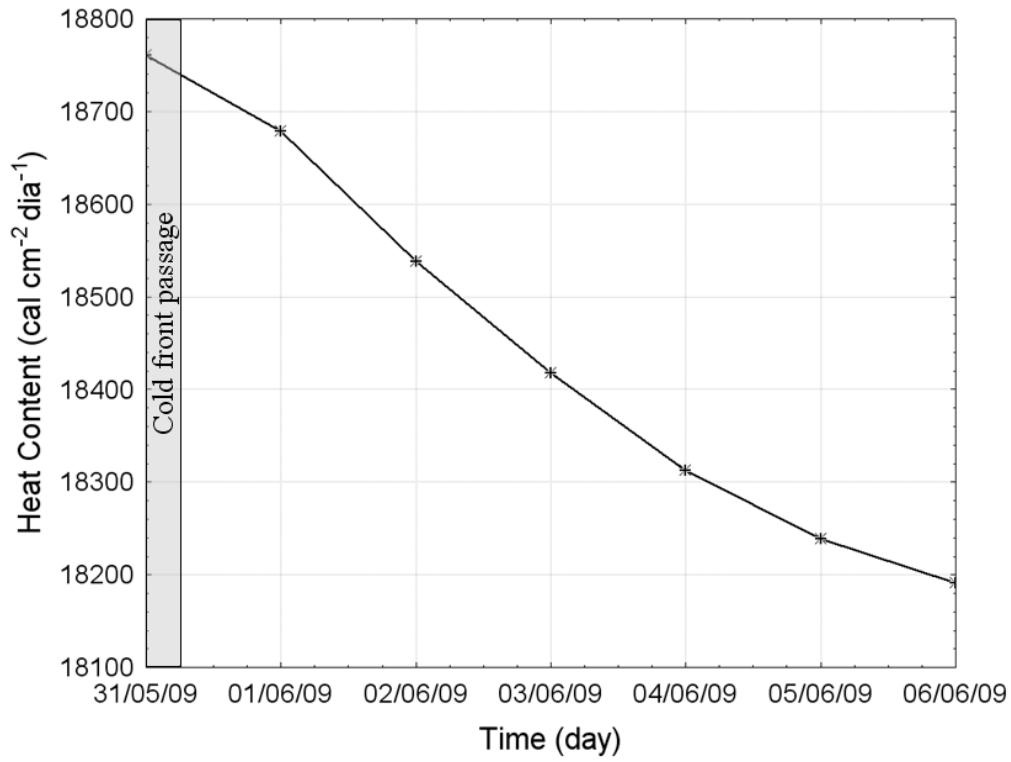

Fig. 9. Heat content (cal cm${ }^{-2} \mathrm{dia}^{-1}$ ) stored in the Itumbiara reservoir during the passage of the cold front. 


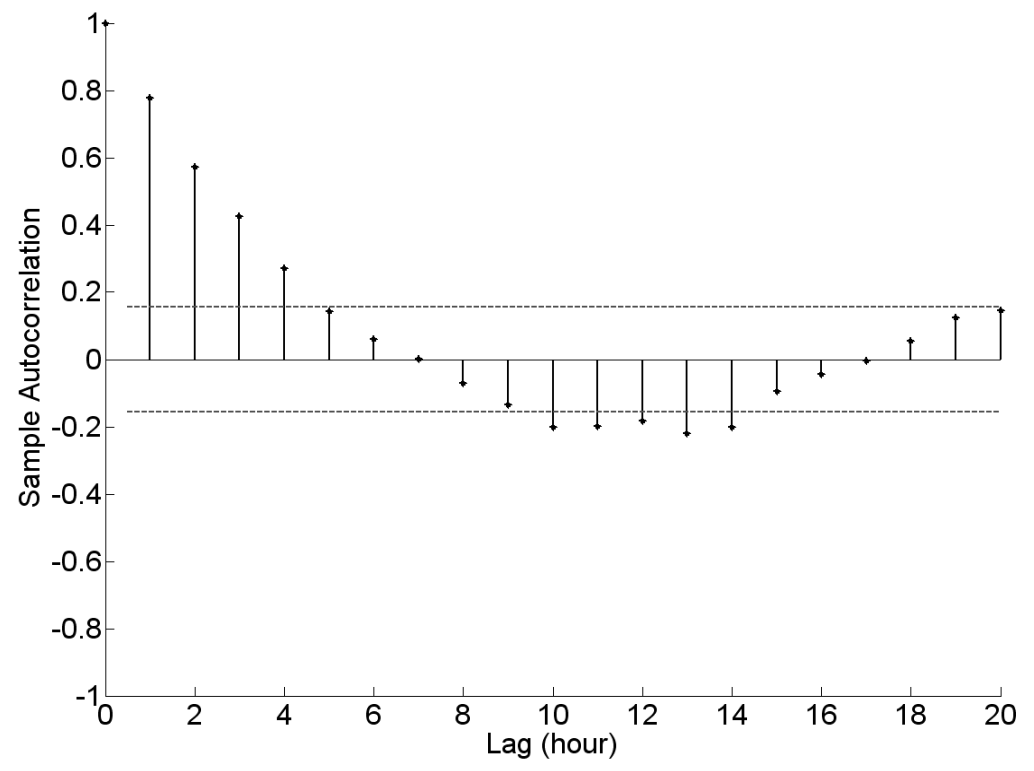

Fig. 10. Wind persistence evaluation through the autocorrelation function.

(a)

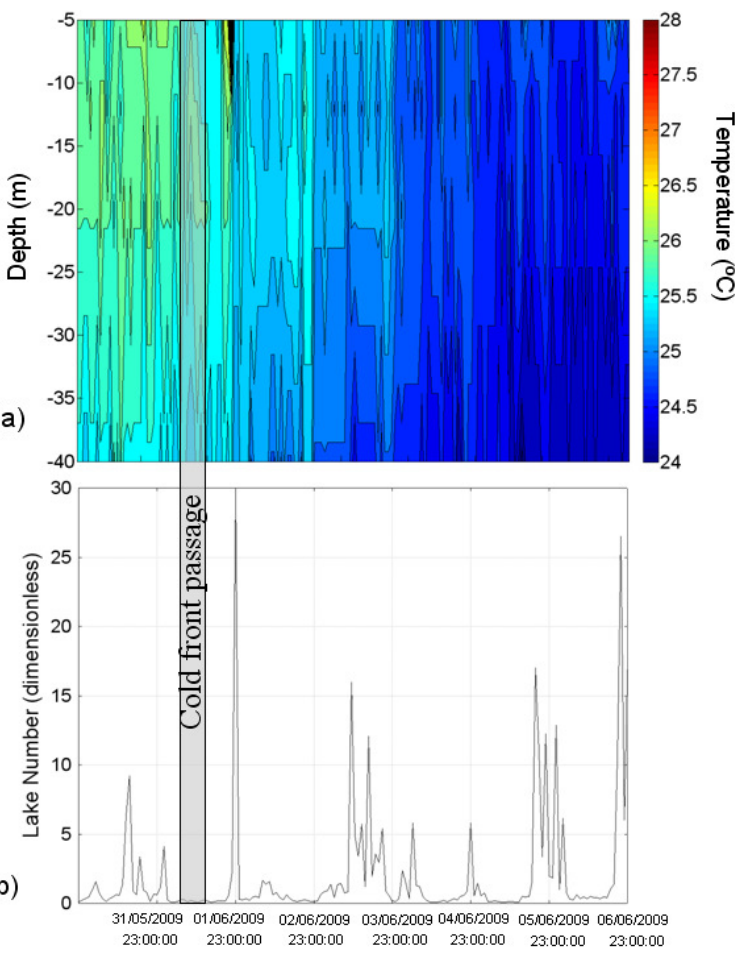

Fig. 11. Thermal structure (a) and the lake number $-L_{N}$ (b) for the Itumbiara reservoir. 


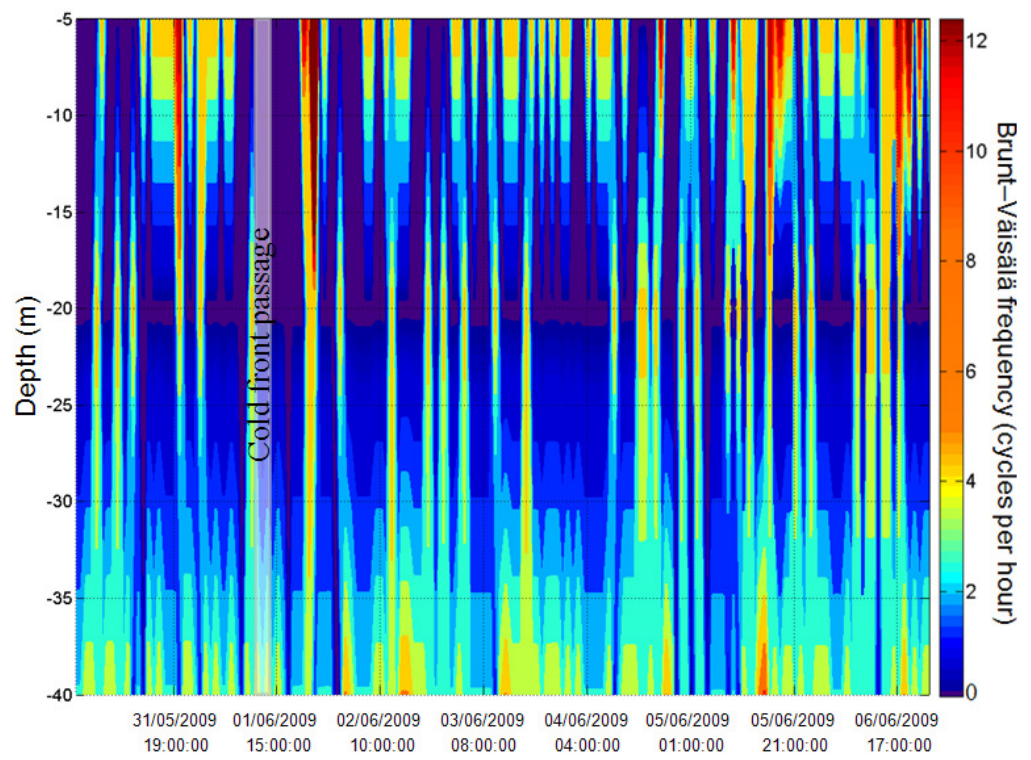

Fig. 12. Water column stability from Brunt-Väisälä frequency (cycles per hour). 